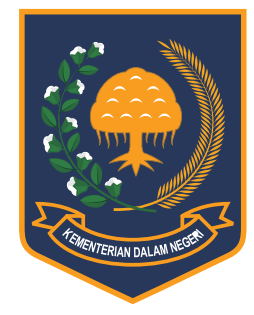

Jurnal Bina Praja 10 (1) (2018): 111-119

Jurnal Bina Praja

e-ISSN: 2503-3360 | p-ISSN: 2085-4323

Accreditation Number

735/AU2/P2MI-LIPI/04/2016

http://jurnal.kemendagri.go.id/index.php/jbp/index

\title{
The INVOLVEMENT OF MASS ORganizations (ORMAS) IN ILLEGal LeVIES Practices IN WEST JAVA
}

\author{
Purwadi*, M. S. Rifki, Tomo Hadisaputra, Leydi Silvana \\ Research and Development Agency, \\ Ministry of Home Affairs, Republic of Indonesia \\ Jalan Kramat Raya No. 132, Senen, Central Jakarta
}

Received: 17 February 2018; Accepted: 11 April 2018; Published online: 12 May 2018

DOI: $10.21787 / j b p .10 .2018 .111-120$

\begin{abstract}
The Mass Organizations (Ormas) that supposed to contribute to a good, clean government, free of corruption, collusion and nepotism, did exactly the opposite. The Anti-Illegal Levies Raids (OTT) where the alleged perpetrators were caught red-handed by the Anti-Illegal Levies Task Force (Satgas Saber Pungli) involved the mass organizations and thugs. The weak integrity and credibility of Ormas was a major government issue. To that end, the goal of this study was to understand the involvement of Ormas in illegal levies cases in West Java. The method used in this study was the descriptive method with a qualitative approach, Data collection technique was using the interview technique with inductive analysis and purposive sampling. The study found that many unscrupulous organizations pursued illegal levies and that it tended to be difficult to prove, although it massively occurred. Such as corrupted grants, extorted schools, collected illegal levies, demanded Hari Raya (THR) allowances, and exploited the government's weakness in the Technical Implementation Unit Office (UPTD) of Education. The mass organizations should be registered and monitored as soon as possible to ensure that the problematic organizations can be disciplined.
\end{abstract}

Keywords: Illegal Levies, Mass Organization, Anti-Illegal Levies Task Force

\section{INTRODUCTION}

This study was conducted on the involvement of Mass Organizations (Ormas) in the practice of illegal levies (pungli) in West Java, associated with Presidential Regulation Number 87 of 2016 on the Anti-Illegal Levies Task Force. Mass Organization referred to in this study are as set forth in Law Number 17 of 2013 on Mass Organizations. The Law explains that Mass Organizations are organizations established and formed by the community voluntarily, based on the similarity of aspirations, wills, needs, interests, activities, and objectives to participate in the development of the country to achieve the objectives of the Unitary State of the Republic of Indonesia based on Pancasila. Illegal levies are defined as charges conducted illegally or in violation of the laws and regulations, by and for the personal interest of the perpetrators. Illegal levies are the abuse of authority, which purpose is to speed up the service or fulfill the interests of the payer. Another term for illegal levies is extortion, i.e. a demand by an official to the public in exchange for ease of processing something or to skip several pre-requisite conditions that should be available based on the prevailing regulation (Wibawa, Fauzy, \& Habibah, 2013, p. 75).

Recently the Mass Organizations are synonymous with intolerance, crime, and even illegal levies. Illegal levies are one of the crucial issues for the government. Since illegal levies are often systematic and organized from the grassroots/lowest level to the senior government officials, either at the central and regional levels (2017). Apparently, the illegal levies in Indonesia are growing systemically. Illegal levies in school are no longer seen as a violation of law, it has been routinely conducted and it has become a deeprooted culture. Presidential Regulation Number 87 of 2016 on Saber Pungli Task Force was issued by President Joko Widodo because the illegal levies

\footnotetext{
* Corresponding Author

Phone : +62 89623152483

Email : alqo0901@gmail.com
} 
were increasingly distressing the community and considered to make the Indonesian business world to be increasingly difficult to compete with other countries. Saber Pungli Task Force was formed, up to the regional areas including West Java. West Java has the highest illegal levies case caught by the Saber Pungli Task Force through its operations. Data from Secretariat of Saber Pungli Task Force of West Java Province 2017 stated that up to 2016, 9 cases of illegal practices caught in West Java with 26 persons as the suspects, including one Head of One-Stop Service Center (PTSP) of Bandung City Government, with the evidence of Rp364 million, 34 thousand US Dollars, 124 Pounds Sterling, a bank saving book with a balance of Rp500 million, two cars, and one motor unit. It was the largest in Indonesia from the 41 cases caught in 20 areas.

Apparently, the illegal levies practices are not only performed by the persons who work in the Government to the public who need to obtain licenses, but also by mass organizations to the Government and the public. The issuance of the presidential regulation was an eye-opener, that the illegal levies occurred massively. On March 20, 2017, for example, the police arrested members of the Koperasi Tenaga Kerja Bongkar Muat Samudra Sejahtera (Komura), a labor cooperative and Pemuda Demokrat Indonesia Bersatu (PDIB) youth organization which extorted containers and vehicle parking in Palaran Harbor, Samarinda. they also entered into unilateral working agreements on all Crude Palm Oil (CPO) and coal companies in East Kalimantan. Kompas.com stated that the companies are required to pay fees for labor services and pay a charge of Rp180 thousand - Rp350 thousand per container, while the legal charge for loading at Tanjung Perak Port is only Rp10 thousand per container. They receive at least Rp3 billion per month from each of the CPO and coal company (Abelda Gunawan, 2017).

Not only in Samarinda, East Kalimantan, the illegal levies practices committed by the mass organizations also took place in Bogor and Cimahi. In Bogor, West Java, the truck drivers conducted activities in the market area was charged by a mass organization. There were at least 30 to 50 loading/ unloading activities each day, for each activity the perpetrator collected Rp50 thousand to Rp75 thousand (VentoSaudale/CAH, 2017). In Cimahi, West Java, five members of the Gabungan Inisiatif Barisan Anak Siliwangi (Gibas) organization were arrested by police in Jalan Kawasan Industri, Cimahi city. Their modus operandi was by collecting money from the truck drivers passing the street under the pretext of security participation money. Merdeka. com reported, that Gibas organizations were making tickets with the nominal of Rp3 thousand and Rp5 thousand based on the type of cargo (Andrian Salam Wiyono, 2016).

The number of mass organizations in Indonesia continues to grow from 139,957 in 2013 to 344,039 in 2017. There is no exact number of mass organization in West Java. In 2012 there were 527 mass organization/NGOs registered in Bandung District (Pikiran Rakyat, 2012). Other data also showed that there were 1,126 organizations/NGOs in Bandung until the end of 2013 (Data Kesbangpol unit of West Java Province 2017). Just imagine, if one district has 500 organizations, how many would the West Java province has, with its 18 districts and 9 cities. The growth of the mass organization in Indonesia is without strict supervision, which then leads to various legal issues (MSR, 2017). Ministry of Home Affairs data up to July 2017 showed that there were 344,039 mass organizations in Indonesia. These Organizations were listed in several institutions, such as the Ministry of Home Affairs, the Ministry of Foreign Affairs, the Ministry of Justice and Human Rights, in the provinces and Districts/Cities. The Ministry of Home Affairs stated that there are 22,486 organizations recorded in Ministry of Home Affairs, Provinces and Districts/ Cities. 70 of them registered in the Ministry, 7,226 registered in the provinces, and the other 14,890 registered in districts/cities. There were 321,482 organizations registered in di the Ministry of Justice and Human Rights, and 71 registered in the Ministry of Foreign Affair. According to the Directorate General of Politics and Public Administration of the Ministry of Home Affairs, tens of thousands of mass organizations recorded in the Ministry of Home Affairs has not been incorporated (Puspen Kemendagri, 2017).

So far, existing studies on mass organizations had been about the benefits of a cooperation between the NGOs/Mass organizations with the government. Existing studies on the illegal levies has been conducted to understand how the levies were conducted by the government's employees, however, a study on the involvement of mass organizations in the practice of illegal levies has not been conducted. The study conducted by Yusdianto (2012) for example concluded that the presence of mass organizations and NGOs played an important role in development. NGOs/Mass Organizations were in equal position and parallel with the government, as such it was beneficial for the government to collaborate with the mass organizations/NGOs. Yusdianto did not examine the conflict between the government and mass organizations in detail, but rather on the synergy that could be made between them. Ramadhani (2017) and Taha (2014), studied the Illegal levies in the public sector. In their studies, Ramadhani 
and Taha concluded that the public service sector is the way for low-level employees to charge illegally. The illegal levies were defined as a bribe to solve problems. Ramadhani found that illegal payments were generally conducted in the office, while Taha analyzed that it occurred in a massive manner to the low-income community member such as bus and truck drivers. According to Taha, an effective coaching was needed, accompanied by the supervision of the bus/truck drivers to pay more attention to their vehicle paper and licenses, and to obey the rules of traffic, to avoid the illegal levies.

Other studies were conducted by Rutdatin (2017), Rustiyanto (2014), and Askar (2017). According to Rutdatin and Rustiyanto, there are illegal levies in the licensing system such as IMB permit. It is time to have preventive efforts to handle the illegal levies practices. There should be efforts to increase public and government apparatus awareness in avoiding the illegal practices. Askar stated that the efforts should refer to Presidential Regulation Number 87 of 2016 which focuses more on public service, and most importantly the adequate planning of the Saber Pungli Task Force. This study differed with studies conducted by Taha, Ramadhani, Rutdatin, Rustiyanto, and Askar. Their research examined the functioning of victims, the inhibiting factors to implement the eradication program of illegal levies, the role of executor of the illegal levies eradication policy, and alternative efforts in handling it, while this study focused on the involvement of Mass Organization in the Illegal levies practice. The involvement of Mass Organizations is important to be studied in depth, especially in relation to how the Mass Organization conducted their actions.

The discussion section will discuss the involvement of the Mass organizations in the illegal levies practices in West Java, the methods used, the illegal levies practices, illegal levies by mass organizations, corruption of grants, illegal levies in schools and on drivers, extortion of mini market for allowances (THR), and other levies.

\section{METHOD}

This study used the descriptive method with a qualitative approach to achieve the study's objectives. Kirk \& Miller (2016, p. 5) stated that the descriptive qualitative study is in the form of words and images, not in numbers. Their statement is in line with this study, the data obtained from the interview and the secondary data in the form of numbers were re-described in a write-up. Some of the information and data from this study were obtained from some credible and reliable online media since the data on the involvement of Mass Organizations in Illegal Levies practices were very minimal and difficult to prove by the informant, although it was in a massive proportion. The collected data were then analyzed to see the factors causing the involvement of mass organizations in the illegal levies practice, to seek a solution to the phenomenon.

This study was conducted in West Java Province for one month, precisely in November - December 2017. This location was deliberately chosen because the area of West Java Province had the most illegal levies practices at the end of 2016. The sources of this study were selected using the purposive sampling method. The sources were chosen in accordance with the criteria that have been established based on the study needs. There were 4 types of sources, namely Saber Pungli Task Force of West Java which were the Head of Data and Information Unit Mr. Yudi Ahadiat, the employees in the Inspectorate of Territories, the staff at the National Unity and Politics Agency (Kebangpol) of West Java, including The Head of the Economy Resilience, Arts, Culture, Religion and Society Enih Srimurni, and members of Anti-Corruption organizations from Indonesian Writer journalist Association (Ikatan Penulis Jurnalis Indonesia/ IPJI) West Java Ai Mulyani, and the community. The sources were those considered the most credible and could answer the purpose of study. According to Arikunto (2006, p. 112), the purposive sampling is a sampling technique that is not based on random, regional or strata, but for but based on the focus on a particular purpose. The data collection method in this study was using the interview method. The data analysis techniques were using the inductive data analysis, i.e. data reduction (recording, summarizing, and analyzing data), displaying data (presenting previously collected and analyzed data), and drawing conclusions/verifications (drawing conclusions based on findings and verifying data).

\section{RESULTS AND DisCUSSION}

Saber Pungli was part of President Joko Widodo's first legal policy package. The eradication of illegal levies was one of the priorities due to the many complaints about it received by the President. Kompas.com (2016) stated that after a month of its formation, on November 22, 2016, the Illegal levies Eradication (Saber Pungli) Task Force received 10,520 reports from the public. Based on Article 2 of the Presidential Regulation Number 87 of 2016 on Saber Pungli Task Force, Saber Pungli duty is to implement the eradication of illegal levies effectively and efficiently by optimizing the utilization of personnel, work units and facilities, in ministries/ agencies or even regional governments, including the Government of West Java Province. 


\section{A. Illegal Levies in West Java}

After the enactment of the Presidential Regulation Number 87 of 2016 on the Saber Pungli Task Force, there were many reports from the public lodged to the Task Force, which later led to various cases of the anti-illegal levies operation (OTT). Based on data from Saber Pungli Task Force OTT operations 2016 released by the Head of Public Information unit of the Police Public Relations Division at that time (Commissioner Martinus Sitompul), there were approximately 410TT results conducted by the Police and Inspectorate in the ministries/institutions. In 20 provinces, namely West Java, East Java, North Sumatra, Aceh, Banten, in Yogyakarta, Indonesia, Jambi, West Kalimantan, Kaltim, Kepri, North Maluku, Lampung, West Nusa Tenggara (NTB), East Nusa Tenggara (NTT), South Sulawesi, Central Sulawesi, North Sulawesi, West Sumatra and South Sumatra. The largest evidence is obtained in East Java province, which was about Rp2 billion, while the lowest are obtained in Gorontalo Province, namely Rp45 thousand. The Saber Pungli OTT also conducted in two State agencies, i.e. the Attorney General's Office, and the police. One in the Attorney General's Office confiscated Rp1.5 billion of evidence, while two OTT the national police confiscated Rp3.43 billion involving three suspects (Source: Secretariat of Task Force Saber Pungli West Java Province, 2017).

The presence of Saber Pungli Task Force in West Java province was based on the decision of the Governor of West Java, Number 700/ Kep/1089/2016, on November 4, 2016, regarding Saber Pungli Task Force in West Java province. Less than two years after the formation of Satgas Saber Pungli Task Force in West Java, the Illegal Levies cases revealed by Saber Pungli Task Force Team of West Java Province is significant, 213 cases, where 21 cases through UPP (Provincial Public Service Unit), and 192 cases through the UPP (Public Service Unit) of the District/City, with the amount of evidence of Rp1,049,790,900 (Source: Secretariat of Task Force Saber Pungli West Java Province, 2017). The types of the illegal levies revealed by Saber Pungli Task Force Team of West Java Province can be seen in Table 1.

Table 1.

The Type Illegal Levies in West Java Province Up to End of 2016

\begin{tabular}{cccc} 
No. & & Type & Cases \\
1 & Public transport & 76 \\
\hline 2 & Market/Seller & 23 \\
\hline 3 & Parking & 23 \\
& & Number & 183
\end{tabular}

\begin{tabular}{|c|c|c|}
\hline No. & Type & Cases \\
\hline 4 & Vehicles & 19 \\
\hline 5 & Extortion & 9 \\
\hline 6 & Fraud and embezzlement & 8 \\
\hline 7 & Vehicle Testing & 6 \\
\hline 8 & Land & 6 \\
\hline 9 & National ID card/Family card/Birth certificate & 5 \\
\hline 10 & Project & 5 \\
\hline 11 & Mining and quarrying & 4 \\
\hline 12 & Licensing services & 3 \\
\hline 13 & Bribery in law enforcement/court cases & 3 \\
\hline 14 & Immigration & 1 \\
\hline \multirow[t]{2}{*}{15} & Driver's license & 1 \\
\hline & Number & 183 \\
\hline
\end{tabular}

Source: Secretariat of Task Force Saber Pungli West Java Province, 2017

Of the 213 cases of OTT conducted by Saber Pungli Taskforce, only 135 cases were followed up or upgraded to investigation process, $\mathrm{P}$ (fixed) were 0 cases, and P-21 (notification that the investigation result is complete) were 8 (eight) cases. 4 cases were tried in court, 3 cases were submitted to the relevant agencies, and 64 were prevention cases. Cases involving illegal fees in West Java include 421 people, 74 civil servants/civil state apparatus (ASN), 68 daily casual workers (PHL)/non-permanent employee, and 8 armed forces/Police personnel. The illegal levy cases in West Java originated from the public report through direct reports (34 cases), and 44 reports from e-mail, call centers, and social media. The involvement of the general public is very dominant in comparison to Mass Organizations/ NGOs. The Mass Organizations/NGOs was also part of the target of the Task Force operation (source: Secretariat of the Inspectorate Area of West Java, 2017).

In Tasikmalaya District of West Java Province, for example, a combined Team from the Inspectorate, National and Political Unity Office (Kesbangpol), and Public Order Unit (Satpol PP) conducted a raid at the Office of Department of Transportation District of Tasikmalaya on 9 November 2016. During the raid, officers found one of the bus crew who was extending the Vehicle Test (KIR) period. The bus driver stated that he had given a payment of Rp200 thousand to a Transportation Department officer at the registration counter for the extension of the KIR 
period, the amount was demanded by the officer, whereas the KIR test is only Rp85 thousand. The driver put money into a white envelope on to speed up the testing process.

\section{B. The Various Ways the Mass Organization Charged the Illegal Levies}

According to the Secretary of the Inspectorate of the Province of West Java, the illegal levies was caused by 1) bad ethics, (2) abuse of authority, (3) salary that did not commensurate with position, (4) organizational or cultural habits, and (5) desire to own more property, and (6) weak supervision. From the organization aspect, the factors were: (1) lack of leadership, (2) lack of good organizational culture, (3) lack of accountability system in government institutions, and (4) weak management control system (personal communication, November 29, 2017).

In contrast to the opinion of the Inspectorate Secretary of West Java region, one member of the Saber Pungli Task Force stated that the West Java illegal levy cases occurred due to a lack of understanding of the religion. The perpetrators tend not to have the attitude and skill/knowledge of their field of work. He added that illegal levies were also caused by consumptive lifestyle, hedonism, and unhealthy work environment conditions. To eradicate Illegal Levies, the Saber Pungli task force of West Java conducted some prevention efforts to the ASN to build their character. For example, the team had socialized the Stop Pungli, counseling, training, electronic-based prevention, and accelerate the establishment of Saber Pungli Unit (USPI) as the quantum change effort or personal transformation of the ASN. In the socialization events, the team emphasized, that the ASN must avoid such corrupt behavior of small-scale illegal levies. These small things would later become a large case of illegal levies. The Team also stressed to avoid levies that were not in accordance with the law, particularly in the public service area. According to one Task Force member, the illegal levies caused the ASN personnel to lose their identity as a servant to the public. (personal communication, November 29, 2017).

The eradication effort of illegal levies had been carried out by the West Java government. A number of eradication programs were launched. such as e-Samsat, an easy way to pay tax on the income sector, and the Employee Income Benefit Management (TPP) system in the employee benefits sector, including the West Java's One Access Always Sympathetic (Satu Akses Pasti Simpatik) Innovation for the licensing sector. Some of these programs are even defined as the "pilot project" for the prevention of corruption and illegal levies for 17 provinces in Indonesia by the Corruption Eradication Commission (KPK) in 2016 The Government of
West Java Province also invited all components of the wider community including mass organizations in its territory to participate in overseeing the performance of the government, and all District/ City Government in West Java Province, by filing a report if there were actions outside the applicable rules and regulations, either directly or indirectly, through electronic or non-electronic means in the form of information, complaints, reporting, and/ or other forms in accordance with the provisions of the law. This is in line with the study conducted by Wibawa et al (2013, pp. 78-84) which stated that the external supervision by the bureaucrats generally has not been able to stop the phenomenon, and recommended that some community groups including Mass Organizations/NGOs also conducted a random monitoring.

According to one source from West Java Provincial Kesbangpol Unit, the Mass Organizations / NGOs in West Java were not recorded, not even classified since 2013 Some of the organizations claimed to be in the field of culture, but in practice, they acted as the mover of the masses. Organizations that are actively involved in its activities were minimal. Kesbangpol Secretariat of Bandung District West Java Province also recorded 70 percent of 126 organizations/NGOs were not properly administered. For example, they had never filed an administrative report within 14 days after the grant disbursement. Kesbangpol West Java had to work hard to directly followed up with these mass organizations. Most Mass Organizations only filed a complete administration reports at the end of the year, after receiving a reprimand.

In addition to improper administration, it is not uncommon for mass organizations to conduct illegal levies. With the formation of the Saber Pungli Task Force, it is clear that the illegal levy case is not only conducted by public servants. Strict monitoring of illegal levies does not deter the mass organizations to launch various actions. They have a variety of ways to trick the Saber Pungli Task Force, some of them are by corrupting the grants, extort an illegal levy to schools as if it is on behalf of Kesbangpol, charging illegal levies, demand payment of holiday allowance (THR) to the mini-marts, and make use the weakness of the Government in the Technical Implementation Unit Office (UPTD) of education. According to Wijayanto and Zachrie (2010, p. 36), the extent of illegal levies is due to cultural and cultural factors of the organization. Cultures that are formed in an institution that continuously exposed to illegal fees and bribery would lead to illegal levies seen as something ordinary. The condition is also aggravated by the public's misconception on the levies. It is increasingly difficult for the public to distinguish between the legal and the illegal levies. Under these conditions, the illegal fees became an 
organized crime that appeared in the form of Mass Organizations.

\section{Corruption of Grant Funds}

Grants in the regional budget (APBD) are intended to support the achievement of the regional government programs. However, the disbursement of grant funds is often misused with various modes. The most frequently found mode of misappropriation of grants is by inflating the amount of fund needed, the establishment of fictitious institutions, to embezzle the funds for various reasons. The cases that often occurred in West Java is the illegal levy of the grants. In 2017, Kesbangpol disbursed grants to the Mass Organizations and NGOs amounted to Rp3.51 billion which was divided into two terms. The amount of funds received by the respective Mass Organizations/NGOs vary, in the range of Rp15 million - Rp75 million. The West Java government's grant has always been the biggest every year. Data Center for Budget Analysis (CBA) stated that in 2017 budget for grants and social support of West Java was Rp38,479,445,000, followed by East Java with a total of Rp6,440,091,440,000 and Central Java Rp248,562,000,000. (Officer West Java Kesbangpol, personal communication, 2017).

Grants or direct assistance programs of the Government to the public often becomes an easy target the Organizations to embezzle. When the funds are disbursed, the Mass Organizations often ask for percentages in return, as a gratitude in handling various processes, such as licensing, drafting proposals and so forth. They also often claim to be intermediaries and volunteers who contribute to the grant disbursement. Grant that came down from the government is never intact because there are always cuts. The fund is supposed to be used for the development or activities as stated in the proposal, on the memorandum of understanding, on the Regional Grants Agreements (NPHD).

In addition, the Kesbangpol West Java officer stated that many mass organizations/NGOs applied for grant aid stated that they act on behalf of the West Java Kesbangpol or the Ministry of Home Affairs. The Mass Organizations/NGOs are also often did not have a clear addressed and was found as fictitious afterward. As happened in 2012 in Bandung. The loss of grant disbursement to a Mass Organizations/NGO reached to Rp8.1 billion. Mass organizations member who claimed to act on behalf of the Young Entrepreneurs Alliance request funds to the government for 11 NGOs and Mass Organizations under its supervision. The perpetrator used a people names and coordinated grant receipts for some fictitious organizations/ NGOs. There were 39 applicants, consisting of 38 NGOs and 1 cooperative. After the terms and conditions for obtaining the grant were met, the defendant then submitted a request to the Regional Finance and Asset Management Office (DPKAD). Of that fund, the heads of the NGOs who were used in the proposal obtained Rp1-7 million.

With these conditions, a solution to minimize the embezzlement practice is needed. Several previous studies suggested that fund transfers are important to maintain/ensure the achievement of public service standards. Abidin (2015, p.65 and 72) declared that fund disbursement is the most effective means for the community welfare development activities. Fund disbursement is also directed at improving the quality of public services and reducing public service gaps. Disbursement of Grant through a non-cash transaction is also the hope of President Joko Widodo to ease the identification process and usage pattern of the funds and ascertained the recipient was indeed the person in question, not another person. In addition, the Minister of Finance Regulation Number 254/ PMK.05/2015 stipulates that the government regulates the channeling of funds in the form of cash, goods or services. But, more transactions were encouraged to use cash transfer scheme. Based on this regulation, there are at least three ways of cash disbursement for the social assistance fund. First, directly from the State Treasury to the account of the recipients. Second, disbursement from the State Treasury to a non-government institution account. Third, disbursement from the State Treasury to the bank/post account of the intermediary. Grant funds disbursed through banks/Post account of the intermediary is conducted if the recipient is unable to receive them directly. To avoid misuse by certain parties, the government required that the social assistance fund is channeled through registered electronic money account.

The mechanism for granting social assistance fund electronically will provide accurate historical data and ease the monitoring of the use of funds and the behavior of recipients of the social assistance funds. The technology to assist the Supervision of grants also needs to be developed. The provision of grants using online method has a significant role in overcoming the various weaknesses and violations that occurred in the process of distributing grants and social assistance during this time. For example, communityparticipation in the process ofmonitoring and evaluating the distribution of grants and social assistance through the sabilulungan.bandung.go.id website, has contributed to solving the problem related to grants and social assistance. All stages of the process from the budgeting to the disbursement of funds at the Bank, the address and photo of the recipients, the amount of money received, the details of the use of money, the Regional Grant Agreement, and the Mayor's Regulations on the details of the use of social assistance are visualized 
online through www.sabilulungan.bandung.go.id (Gemiharto \& Rosfiantika, 2017, p.113).

\section{Illegal Levies in Schools}

Besides embezzled the grants, according to officers from Kesbangpol West Java, there were mass organizations who went to the schools to demand some money for their organization. Not much different from the case in the grants, they used the Kesbangpol Unit of West Java and Ministry of Home Affairs name to extort the schools. They have mostly extorted money for their organizations' activities and operational matters. Illegal levies by the mass organizations do not stop at collecting funding for their activities. there are cases of illegal levies in new student acceptance process (PPDB) too. The number of cases of illegal levies for student acceptance in the academic year of 2017/2018 in West Java was the highest, it reached $48 \%$ from 240 reports submitted to the Service Unit of the Community Services Bureau and Communication Complaints unit of the Inspectorate General of the Ministry of Education (Media Indonesia, 2017). The findings of West Java Ombudsman and Saber Pungli Task Force showed that the illegal levies conducted by mass organizations/NGOs in the student acceptance process not only occurred in one area but in several areas in West Java such as Purwakarta, Bandung, and Subang District. This generally occurred in public schools. The mass organization and some member of the school management exploit the parent wishes to get their children in favorite schools. Based on the report of Republika. co.id the mass organizations demanded money up to Rp35 million for one student. Every location was different. In Purwakarta, for example, one parent was demanded Rp10 million per person. In Subang, the illegal levies were between Rp5 million to Rp15 million (Zuli Istiqomah, 2017).

The object of the illegal levies in schools was not just the parents/guardians or community members who had a dealing with the school, but also targeting the students, teachers, or the principals. Siregar (2016)concluded that in addition to regulation, the Principal was the main cause of illegal levies. According to Siregar, the Principal was the most effective chain in the school to be the object of the illegal levy. The Principals who were not professional in carrying out their duties and functions as principals, especially in terms of budget management from the APBD and APBN often used by unscrupulous mass organizations/NGOs that use the pretext of Law Number 14 of 2008 on Public Information Openness and Law Number 40 of 1999 on the Press as a basis for intimidation and illegal levy. The weakness of the Headmaster's position in performing his duties and functions is due to several reasons. First, there is no clear, firm, detailed, measurable, and transparent regulation of the Principal's recruitment system so that the appointment of the principals is based on like or dislike rather than on capacity, capability, and competence. A transactional politic suspected to be the mode that is often conducted in the process of appointment and dismissal of the principal.

To analyze further, the main weakness was that the Saber Pungli Task Force could not be stationed in several sectors prone to illegal levies (Rutdatin, 2017). The ideal structure of the Saber Pungli Task Force should be tailored to the size of the area they cover as well as the involvement of community leaders and academics. There was also lack of information dissemination regarding the illegal levies on student acceptance, which was not under the Saber Pungli Task Force radar. In the case of student acceptance process, the community was also not given an understanding related to the supervision of the mass organization and civil servants conducts in performing their duties in accordance with applicable regulations. the public understanding of illegal levies practices in the education sector would help the Saber Pungli task Force to prevent it. Askar (2017, p.52) stated that the weaknesses of the Saber Pungli Task Force are that the Task Force members are not dedicated to work in the task force, they are still conducting their main duties. Askar stated that it would be better if the Saber Pungli Task Force members are only working in the task force main task, to eradicate the illegal levies.

\section{E. Illegal Levies Practices Against Truck/ Bus Drivers, Extorting Minimart for Holiday Allowance (THR), and Other Levies}

The practice of illegal levies by mass organizations is not only happening in the government sector on the grant disbursement and in schools by buying and selling student acceptance quota, but also by extorting drivers passing in industrial areas, demanding holiday allowance payment from mini markets, imposing charges in the market, and other levies. According to one source, some members of a mass organizations often conducted illegal levies in Cimahi industrial areas. The statement was reinforced by a statement from Saber Pungli task Force of West Java which stated that in 2016 an operation conducted by the task force nabbed a perpetrator which claimed to be a member of a mass organization with Rp349,600 in his possession. The mass organization claimed to be a mass organization that focused on the cultural field. The illegal levies were conducted by extorting every expedition truck driver that send goods such as mining and garment products. Tickets given to the drivers were fake tickets, with the range of 
Rp1000 - Rp5000. Illegal levies to the expedition truck drivers are indeed common but mostly done by individual persons and thugs.

Other than extortion to the truck drivers, the Mass Organizations also conducted illegal levies against minimart by forcing them to pay the holiday allowance (THR). In June 2017, Polresta Bekasi arrested the members of the Red and White Community which demanded to collect the THR from the mini-mart. The perpetrator also extorted the sellers in front of a minimart in a Bekasi housing complex. From the interviews with Saber Pungli Task Force, another example was in Cimahi, on November 18, 2016, the Police also arrested a Chairman of a Mass Organization for conducting illegal levies. The money was claimed by the perpetrator to be used for a youth organization. The suspect asked for Rp4 million to one of the companies which were paving the roads. Another case also occurred on January 4,2017 , a member of a Mass Organization with the initials RS, was arrested by the personnel of Bogor Police, West Java. RS was arrested for allegedly conducting illegal levies in Anyar Market. The most shocking case of illegal levies was that some Mass Organizations were often exploiting the weakness of the Government regulation in the related offices and then targeted them for extortion. According to the Kesbangpol staff, many regional apparatus organizations (OPD) reported of being extorted by a certain mass organization, both the registered or non-registered ones.

Of the various illegal levies practices, the solution is very clear, optimize the supervision \& monitoring function. Wibawa, Fauzi, and Hibah (2013, p. 74, p. 85) explain how the supervision and monitoring function should be enacted as soon as possible to minimize the illegal levy. It consists of outward-looking strategy and inward-lookingstrategy. The outward-looking strategy is the strategy that can shape the people and institutions outside the organization to be disciplined and lawabiding. The inward-looking strategy is the strategy that can ensure a highly disciplined supervision \& monitoring processes. It is imperative that the government implements both strategies.

First, the outward strategy is implemented to change institutions outside the organizations which are directly involved with it to be discipline and abiding the law. Such institutions were primarily the mass organizations and communities. Illegal levies will continue to occur if the mass Organization and the community awareness is still low. The mass organizations will continue to try various ways to earn a greater income, for the organization and the perpetrator. Likewise, with the parents, they would go an extra mile to ensure that their child would be accepted in a favorite school. The outward strategy strives to instill better awareness to them, better discipline and abiding the law. This could be done by giving heavy sanctions to mass organizations and the communities involved in repressive efforts. Second, the inward-looking strategy This strategy is closely related to efforts to improve the internal institutions that are directly related to the monitoring conducted by Saber Pungli Task Force. To prevent Saber Pungli Task Force to become the target and involved in the practice of extortion, external improvements should be made to encourage the Taskforce to understand the tasks that need to be done. Involving the elements of society and private sectors directly can also minimize the practice of illegal levies in West Java. Such as establishing cooperation with the Banks for the management of levies and payment of entry tuition and recruitment of prospective students. The importance of the role and participation of the people in the eradication of corruption had not been given much attention and studied in depth (Wibawa et al., 2013). Without community involvement, illegal levies will be difficult to abolish.

\section{ConClusion}

Some problems such as illegal fees in grants disbursements, the recruitment of new students, extortion of mini markets, and other cases by the Mass organizations shows that the existence of Saber Pungli Task Force has not been able to stop the illegal levy after its formation. The anti-illegal levies raids have not intimidated the perpetrator. The Saber Pungli Task Force should implement the eradication measures seriously. It should see potential areas for illegal levies more broadly, not just in government regulation and crack down with a heavy sanction to the direct perpetrators, Saber Pungli Task Force should also conduct a more in-depth investigation by involving the community to detect the involvement of others. Further, to minimize illegal levies within the government, a technology-based transaction and reporting system that is easier and can be accessed by the public should also be developed. Lastly, an adjustment to the Saber Pungli Task Force member to be able to cover the necessary area to ensure the maximum effort of the eradication of illegal levies. Registration of the mass organization also important. The registration is needed to ensure that the mass organizations would not conduct unlawful action. Every mass organization should be registered in the Regional Kesbangpol Unit. The Registration also enables the government to detect problematic mass organizations. With the registration, the government would recognize which organizations have a positive contribution to the national development.

\section{ACKNOWLEDGEMENT}

The author would like to thank the Pusat 
Litbang Politik, PUM and Otda BPP of the Ministry of Home Affairs who has assisted this study.

\section{REFERENCES}

Abelda Gunawan. (2017). Wajah Preman Pelabuhan Samarinda Pengutip Pungli Ratusan Miliar.

Abidin, M. Z. (2015). Tinjauan atas Pelaksanaan Keuangan Desa dalam Mendukung Kebijakan Dana Desa. Jurnal Ekonomi Dan Kebijakan Publik, 6(1), 61-76. http://doi.org/10.22212/ JEKP.V6I1.156

Andrian Salam Wiyono. (2016). Pungli sopir truk, lima anggota Ormas Gibas di Cimahi dibekuk.

Arikunto, S. (2006). Metodologi Penelitian. Yogyakarta: Bina Aksara.

Askar, M. (2017). Impelementasi Peraturan Presiden No. 87 Tahun 2016 Dalam Upaya Pencegahan Praktik Pungutan Liar Pada Bidang Pendidikan Di Kabupaten Bulukumba (Perspektif Hukum Islam). Universitas Alauddin Makassar.

Gemiharto, I., \& Rosfiantika, E. (2017). Tata Kelola Pemerintahan dalam Penanggulangan Kemiskinan Melalui Dana Hibah dan Bantuan Sosial di Indonesia (Studi Kasus Tata Kelola Pemerintahan dalam Penanggulangan Kemiskinan Melalui Pengelolaan Dana Hibah dan Bantuan Sosial di Kota Bandung Provinsi . Jurnal Ilmu Politik Dan Komunikasi, 7(1).

Kirk, J., \& Miller, M. L. (2016). Reliabilitas dan Validitas dalam Riset Kualitatif. Jakarta: Rineka Cipta.

Kristian Erdianto. (2016). Satgas Saber Pungli Terima 10.520 Pengaduan dari Masyarakat.

Media Indonesia. (2017). Penyimpangan PPDB Terbanyak di Jawa Barat.

MSR. (2017). Ormas Asing Perlu Pengawasan.

Pikiran Rakyat. (2012). Jumlah Ormas dan LSM di Kab.Bandung Capai 527 Organisasi.

Puspen Kemendagri. (2017). Ini Penjelasan Kemendagri tentang Jumlah Ormas di Indonesia.
Ramadhani, W. (2017). Penegakan Hukum Dalam Penanggulangan Pungutan Liar Terhadap Pelayanan Publik. Jurnal Hukum Samudra Keadilan, 12(2), 263-276.

Risqa Amalia. (2017). Upaya Penanggulangan Pungutan Liar (Pungli) yang Dilakukan Oleh Oknum Kepolisian (Studi: Polresta Padang). Universitas Bung Hatta.

Rustiyanto, K. H. (2014, June). Upaya Polisi dalam Menanggulangi Pungutan Liar terhadap Sopir Truk Galian C di Wilayahkabupaten Sleman. Jurnal Ilmu Hukum. Program Studi Ilmu Hukum.

Rutdatin, D. (2017). Peran Pemerintah Kota Semarang dalam Pemberantasan Pungutan Liar Di Pelayanan Publik (Studi Kasus: Pelayanan Perizinan Izin Mendirikan Bangunan Di Dinas Penanaman Modal dan Pelayanan Terpadu Satu Pintu Kota Semarang). Universitas Diponegoro Jl.

Salamat Siregar. (2016). Memutus Mata Rantai Pungli di Sekolah. Padangsidimpuan: Kemendikbud.

Taha, N. (2014). Tinjauan Viktimologis Pungutan Liar Oleh Oknum Kepolisian Terhadap Pengemudi Angkutan Kota Antar Daerah Di Kabupaten Sinjai. Universitas Hasanuddin.

Vento Saudale/CAH. (2017). Lakukan Pungli, Anggota Ormas di Bogor Ditangkap.

Wibawa, S., Fauzy, A., \& Habibah, D. A. (2013). Efektivitas Pengawasan Pungutan Liar di Jembatan Timbang. Jurnal Ilmu Administrasi Negara, 12(2), 74-85.

Wijayanto, \& Zachrie, R. (2010). Korupsi Mengorupsi Indonesia: Sebab, Akibat, dan Prospek Pemberantasan. Jakarta: Gramedia Pustaka Utama.

Yusdianto. (2012). Konstruksi Kerjasama LSM dan Pemerintah dalam Pembangunan Daerah: Perspektif Undang-Undang Keormasan. Fiat Justitia Jurnal Ilmu Hukum, 6(2).

Zuli Istiqomah. (2017). 120 Laporan Praktek Maladministrasi PPDB 2017 di Jabar. 